\title{
NIKAH SIRRI DALAM PERSPEKTIF YURIDIS DAN SOSIOLOGIS
}

\author{
Nurwahidah \\ Dosen Fakultas Syariah dan Ekonomi Islam IAIN Antasari Banjarmasin \\ E-mail: nurwahidah-97@yahoo.co.id
}

\begin{abstract}
Married siri is carried out by the community, with various shapes and reasons. Scholars who allow their marriage Sirri when harmony and marriage requirements are met, the opportunity for most citizens of the community to do this practice, even in another form that ignores harmony and the terms of the wedding itself. When the mayor is absent or does not approve, they were reluctant to marry guardian judge, but chose to do it Sirri marriage outside legal procedures. They forget that marriage is a strong bond, which binds husbands and wives inwardly and outwardly with certain consequences, both to the couple itself and to children offspring.
\end{abstract}

\begin{abstract}
Abstrak: Nikah sirri masih banyak dilakukan oleh masyarakat, dengan berbagai bentuk dan alasannya. Adanya ulama yang membolehkan nikah sirri apabila rukun dan syarat pernikahan terpenuhi, membuka peluang bagi sebagian warga masyarakat untuk melakukan praktik ini, bahkan dalam bentuk lain yang mengabaikan rukun dan syarat pernikahan itu sendiri. Ketika wali tidak ada atau tidak merestui, mereka enggan menikah dengan wali hakim, tetapi memilih melakukan nikah secara sirri di luar prosedur hukum yang berlaku. Mereka lupa bahwa nikah adalah ikatan yang kuat, yang mengikat suami dan istri secara lahir dan batin dengan konsekuensi-konsekuensi tertentu, baik terhadap pasangan suami istri itu sendiri maupun terhadap anak-anak keturunannya.
\end{abstract}

Kata kunci: Nikah sirri, kedudukan dan akibat bukum

\section{Pendahuluan}

Naluri (gharizah) manusia yang paling kuat ketika sudah memasuki usia remaja dan dewasa adalah melakukan perkawinan (gharizah jinsiyab) guna menyalurkan kebutuhan biologis, sekaligus melahirkan keturunan untuk kesinambungan manusia dari satu generasi ke generasi berikutnya. Dibanding naluri makan, minum, tidur dan lainnya, gharizah jinsiyah ini tergolong kuat dan selalu membutuhkan pemuasan. Bilamana tidak ada penyalurannya maka banyak manusia yang mengalami kegoncangan atau melakukan suatu perbuatan maksiat. Kawin merupakan jalan alami yang paling baik dan sesuai untuk menyalurkan dan memuaskan naluri seks tersebut, sehingga seseorang menjadi tenang dan terhindar melakukan perbuatan haram. ${ }^{1}$

Allah Swt mensyariatkan perkawinan sebagai sarana manusia untuk menyalurkan kebutuhan biologisnya, dan untuk keperluan tersebut Allah telah menciptakan manusia berpasangan-pasangan, ada pria yang kelak menjadi suami dan ada wanita

\footnotetext{
1 Al-Syaikh Sayyid Sabiq, Figh al-Sunnah, Jilid II, (Beirut: Dar al-Fikr, 1403 H), hlm. 10.
}

yang akan menjadi istri. Di dalam Alquran begitu banyak ayat yang berkenaan dengan perkawinan tersebut. ${ }^{2}$ Begitu pula dalam sejumlah hadis, begitu banyak ajaran Rasulullah kepada umatnya untuk melangsungkan perkawinan. Kalau ada di antara sahabat Rasulullah yang enggan kawin, beliau segera menyuruhnya kawin, dan kalau ada sahabat yang mengabaikan lembaga perkawinan, beliau segera meluruskan sikap tersebut.. ${ }^{3}$

Perkawinan yang disyariatkan dalam Islam bersifat ibadah, bukan sebagai sarana untuk melampiaskan hawa nafsu seksual saja. Perkawinan merupakan ibadah dan bertujuan untuk mewujudkan kehidupan rumah tangga yang sakinah, mawaddah dan rahmah. ${ }^{4}$

\footnotetext{
2 Di antara ayat Alquran tetang perkawinan adalah QS al-Nisa ayat 1 , al-Ra'ad ayat 38, al-Nahl ayat 72, al-Ruum ayat 21, al-Nur ayat 32, al- Zariyaat ayat 49, Yasin ayat 36, dan al-Hujurat ayat 13.

3 Al Imam Abi Abdillah Muhammad bin Ismail bin Ibrahim al-Bukhari, Shabih al-Bukhari, Jilid III, Juz 6, (Beirut: Dar al-Fikr, 1401 H), hlm. 116.

4 Abdurrahman, Kompilasi Hukum Islam di Indonesia, (Jakarta: Akademika Pressindo, 1992), hlm. 114.
} 
Pertanda kuatnya ikatan perkawinn dan untuk menjamin terwujudnya tujuan luhur perkawinan, tata cara perkawinan sudah diatur dengan rukun dan syarat tertentu tertentu. Nikah hendaknya dilakukan secara resmi agar diketahui oleh masyarakat dan dibuatkan dokumennya sesuai dengan peraturan yang berlaku, sehingga perkawinan tersebut memiliki legtimasi baik menurut hukum agama maupun aturan Negara. Perkawinan sirri yang mengabaikan salah satu atau keduanya, tidak saja diragukan legalitasnya, tetapi juga menimbulkan akibat hukum yang merugikan pasangan serta anakanak yang lahir dari perkawinan tersebut.

\section{Perkawinan sebagai Ikatan Yang Kuat Hakikat Perkawinan}

Sunnatullah semua makhluk adalah hidup berpasang-pasangan, begitu juga dengan manusia sebagai makhluk paling mulia di antara makhlukmakhluk Allah yang lain. Perkawinan menurut pandangan Islam merupakan sebuah ikatan perjanjian yang kuat, yang tidak sekadar diikat dan kemudian dilepaskan begitu saja, sebagaimana firman Allah "Dan mereka (istri-istrimu) telah mengambil dari kamu perjanjian yang kuat" (QS an-Nisa: 21$)$

Kekuatan ikatan perkawinan juga diatur di dalam Undang-undang Nomor 1 Tahun 1974 tentang Perkawinan (selanjutnya disingkat UUP) yang diundangkan sejak awal tahun 1970-an, pasal 1 menyatakan: "Perkawinan ialah ikatan lahir dan batin antara seorang pria dengan seorang wanita sebagai suami istri dengan tujuan membentuk (rumah tangga) yang bahagia dan kekal berdasarkan Ketuhanan Yang Maha Esa".

Kuatnya ikatan perkawinan sejalan pula dengan rumusan perkawinan sebagaimana diatur dalam Kompilasi Hukum Islam (selanjutnya disingkat KHI) pasal 2 dan 3: "Perkawinan menurut hukum Islam adalah pernikahan, yaitu akad yang sangat kuat atau mitsâqan ghalìdhan untuk menaati peritah Allah dan melaksanakannya merupakan ibadah. Perkawinan bertujuan untuk mewujudkan kehidupan rumah tangga (keluarga) yang sakinah, mawaddah dan rahmah".

Jelaslah perkawinan atau pernikahan adalah ikatan lahir dan batin antara seorang pria dengan seorang wanita untuk menjadi suami istri, ikatan

\footnotetext{
5 Undang-Undang Nomor 1 Tahun 1974 Tentang Perkawinan, (Surabaya: Pustaka Tintamas, 1991), hlm. 7.

${ }^{6}$ Abdurrahman, Loc cit.
}

itu bersifat kuat dan permanen, dengan tujuan utamanya membentuk keluarga bahagia. Meskipun sekarang sudah ada fenomena pernikahan sejenis, yang dilegalkan di beberapa negara, dan konon juga pernah terjadi di Indonesia, namun dalam hukum yang berlaku di Indonesia ikatan yang terjadi antara sesama jenis, misalnya pria dengan pria, atau wanita dengan wanita, tidak dapat dinamakan perkawinan. Begitu pula kalau hubungan itu terjadi antara pria dengan wanita, tetapi tidak dibentuk melalui akad pernikahan, maka juga bukan pernikahan namanya, seperti halnya perzinaan dan pelacuran. Perkawinan yang dikehendaki adalah yang sesuai dengan hukum yang berlaku, yaitu hukum agama dan hukum negara

Di dalam buku Pedoman Pegawai Pencatat Nikah dinyatakan: Perkawinan adalah sah apabila dilakukan menurut hukum agama, sebab merupakan asas pokok dalam kehidupan kemasyarakatan yang sempurna. Bukan saja perkawinan itu suatu jalan yang sangat mulia untuk mengatur kehidupan dan keturunan, juga dipandang sebagai suatu jalan menuju perkenalan antara satu kaum dengan kaum lainnya. Dengan demikian terjadi saling bertolongtolongan antara satu dengan yang lain.

Disyariatkannya perkawinan di kalangan masyarakat Islam khususnya, disebabkan di dalam perkawinan tersebut terkandung tujuan luhur yaitu untuk menyalurkan kebutuhan seksual secara bertanggung jawab, untuk membina rumah tangga, untuk melahirkan keturunan yang jelas orangtuanya dan untuk mewujudkan tata kehidupan masyarakat yang teratur. Al-Syaikh Sayyid Sabiq mengemukakan beberapa hikmah dan tujuan luhur perkawinan, yaitu:

1. Perkawinan merupakan jalan alami dan biologis yang paling baik dan sesuai untuk menyalurkkan dan memuaskan naluri seksual. Dengan kawin jiwa jadi tenang, badan jadi segar, dan mata terpelihara dari melihat dan menikmati yang haram;

2. Perkawinan merupakan jalan terbaik untuk memperbanyak keturunan, menjadikan anakanak menjadi mulia dan jelas nasabnya;

3. Perkawinan menumbuhkan naluri kebapakan pada suami dan keibuan pada istri, sehingga tumbuh rasa cinta kasih dengan anak-anak

\footnotetext{
Departemen Agama RI, Pedoman Pegawai Pencatat Nikah dan Pembantu Pegawai Pencatat Nikah, (Jakarta: Proyek Peningkatan Sarana Keagamaan, 1996/1997), hlm. 45.
} 
dan timbul rasa tanggung jawab dan semangat untuk bekerja secara sungguh-sungguh.;

4. Perkawinan dapat menumbuhkan tali ikatan kekeluargaan dan kemasyarakatan, sehingga masyarakat menjadi kuat. ${ }^{8}$

Jelaslah bahwa perkawinan mengandung tujuan-tujuan luhur yang sejalan dengan nilai-nilai kemanusiaan dan kemasyarakatan yang adil dan beradab. Perkawinan tidak semata sebagai sarana untuk menyalurkan kebutuhan biologis, tetapi juga tujuan moral dan sosial yang sangat luhur untuk terpeliharanya agama, keluarga dan masyarakat. Perkawinan sejalan dengan tujuan syariat (maqâsid

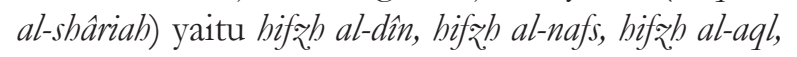
bifž al-nasl dan bif̨̌h al-mâl. ${ }^{9}$

\section{Dasar Hukum}

Hukum yang berlaku di Indonesia yang berkaitan dengan perkawinan mencakup Hukum Islam dan Hukum Negara. Hukum Islam bersumber dari Alquran, hadits dan pendapat para ulama, sedangkan Hukum Negara (Hukum Positif) adalah hukum yang bersumber dari peraturan perundangundangan.

\section{Hukum Agama}

Perkawinan di dalam Alquran tercantum dalam beberapa surah, di antaranya surah an-Nisa ayat 1 yang artinya: "Hai sekalian manusia, bertaqwalah kepada Tuhanmu yang telah menciptakan kamu dari seorang diri, dan daripadanya Allah menciptakan istrinya, dan daripada keduanya Allah memperkembangbiakkan laki-laki dan perempuan yang banyak".

Di dalam surah ar-Ruum ayat 21 Allah berfirman yang artinya: "Dan di antara tanda-tanda kekuasaan-Nya ialah Dia menciptakan untukmu istri-istri dari jenismu sendiri, supaya kamu cenderung dan merasa tenteram kepadanya, dan dijadikan-Nya di antara kamu rasa kasih dan sayang. Sesungguhnya pada yang demikian itu benar-benar terdapat tanda-tanda bagi kaum yang berpikir".

Di dalam surah an-Nuur ayat 32 Allah berfirman yang artinya: "Dan kawinkanlah orang yang sendirian di antara kamu dan orang-orang yang layak berkawin dari hamba-hamba sahayamu yang lelaki dan hamba-hamba sahayamu yang perempuan. Jika mereka miskin Allah akan

\footnotetext{
${ }^{8}$ Sayyid Sabiq, Figh Sunnah, Jilid 6, (Bandung: Almaarif, 1987), hlm. 18-19.

9 Al-Syaikh Sayyid Sabiq, Op. cit, Jilid I, hlm. 10.
}

memampukan mereka dengan karunia-Nya. Dan Allah Maha Luas pemberian-Nya lagi Maha Mengetahui".

Ketiga ayat tersebut menjelaskan bahwa Allah menetapkan syariat perkawinan sebagai cara untuk memperoleh keturunan. Allah jadikan manusia pria dan wanita yang kemudian saling melangsungkan perkawinan untuk mewujudkan kebahagiaan. Allah perintahkan pria dan wanita yang sendirian untuk kawin, karena dengan kawin itu Allah akan meluaskan rezeki untuk mereka. Ketidakmampuan ekonomi tidak dapat dijadikan alasan untuk tidak melangsungkan perkawinan, sebab bisa saja dengan membangun kehidupan berumah tangga, kehidupan ekonomi akan menjadi baik, asalkan suami rajin bekerja dan istri pandai mengatur keuangan keluarga. Betapa banyak pasangan yang sebelum kawin tidak memiliki apa-apa, namun setelah kawin dan memiliki anak hidupnya lebih baik, kariernya lebih berkembang dan berangsur mapan.

Betapa pentingnya perkawinan, hal ini juga ditekankan oleh Rasulullah saw dalam banyak hadits beliau. Diceritakan bahwa pada suatu kali ada beberapa orang sahabat mendatangi rumah Nabi untuk mengetahui perihal ibadah beliau. Berdasarkan penilaian mereka ibadah Nabi itu biasa-biasa saja, tidak begitu istimewa. Kemudian di antara sahabat itu beranggapan bahwa hal itu wajar bagi Nabi sebab beliau seorang yang ma'shum, dosa yang lalu dan yang akan diampuni dan Nabi pasti masuk surga. Berbeda dengan mereka sebagai manusia biasa, tidak ada jaminan bersih dari dosa dan tidak ada jaminan pasti masuk surga. Jadi, beribadahnya harus lebih kuat. Ketiga orang ini kemudian memasang tekad, satu orang ingin shalat sepanjang malam tanpa isitrahat, yang seorang lagi ingin terus menerus berpuasa tanpa berbuka, dan yang seorang lagi tidak ingin kawin supaya konsentrasi ibadahnya tidak terganggu. Dia menganggap perkawinan dapat mengurangi ibadah dan konsentrasi dalam ibadah. Setelah Rasulullah saw mengetahui pendirian sebagian sahabatnya itu, beliau melarang dengan tegas sambil bersabda yang artinya: "Kamukah yang berkata begini dan begitu. Ketahuilah, demi Allah, aku lebih takut dan taqwa daripada kamu, tetapi aku berpuasa dan berbuka, aku shalat dan aku istirahat dan aku juga kawin dengan wanita-wanita. Maka barangsiapa tidak mengikuti sunnahku, maka bukan golonganku". 
(HR al-Bukhari). ${ }^{10}$

Selanjutnya pada hadis lainnya juga dinyatakan yang artinya: "Berkata Abdullah bin Mas'ud: Kami di masa Nabi saw adalah para pemuda yang tidak memiliki apa-apa (miskin), maka berkata kepada kami Rasulullah SAW: Hai para pemuda, barangsiapa di antara kamu mampu kawin maka kawinlah, sebab kawin itu menjaga pandangan dan memelihara kehormatan (kelamin), dan barangsiapa yang tidak mampu kawin hendaklah ia berpuasa karena puasa itu akan menjadi perisai baginya (HR al-Bukhari). ${ }^{11}$ Kemudian pada hadis yang diriwayatkan oleh Imam al-Tirmidzi dinyatakan yang artinya: "Dari Abi Ayyub berkata: Bersabda Rasulullah saw : Empat dari Sunnah para Rasul adalah: rasa malu, berharum-haruman, bersiwak dan nikah" (HR al-Tirmidzi). ${ }^{12}$

Mengacu kepada hadis-hadis di atas jelas sekali bahwa Islam tidak menghendaki adanya orangorang yang menjauhi perkawinan, meskipun dengan alasan yang baik, seperti untuk konsentrasi ibadah. Islam tidak mengajarkan adanya pembujangan seumur hidup sebagaimana dilakukan oleh sebagian rahib dan biarawati agama Katolik, sebab masingmasing anggota tubuh itu mempunyai hak yang harus dipenuhi. Hak perut yang lapar adalah makan, dan hak badan yang bekerja ialah istirahat dan tidur, dan hak organ seksual adalah harus dipenuhi dengan jalan kawin secara benar dan bertanggung jawab melalui ikatan perkawinan yang kuat.

Islam juga menekankan kepada para pemuda untuk melangsungkan perkawinan supaya pandangan mata dan kehormatan akan terjaga, dan bila tidak mampu disuruh berpuasa, sebab puasa akan melemahkan hawa nafsu seksual. Istilah mampu (al-ba'ab) yang dimaksudkan adalah mampu bersetubuh dan mampu membiayai pernikahan. Artinya orang yang mampu keduanya disuruh untuk menikah. ${ }^{13}$ Bagi orang yang sudah ada keinginan bersetubuh, tetapi belum mampu di segi ekonomi, disuruh menahan diri, dengan berpuasa dan menjaga pandangan. Namun berusaha untuk bisa kawin tetap lebih baik, karena, sebagaimana ditekankan di atas Allah akan memberikan karunia

\footnotetext{
${ }^{10}$ Imam al-Bukhari, Loc cit.

${ }^{11}$ Ibid., hlm. 117.

12 Abi Isa Muhammad bin Isa bin Tsaurah al-Turmudzi, Sunan Turmudzi. Jilid 2. (Surabaya: Maktabah Dahlan, tth), hlm. 272.

13 al-Imam Muhammad Ismail al-Kahlani, Subul al-Salam, (Beirut: Dar al-Fikr, 1411 H), hlm. 110.
}

rezeki kepada orang yang kawin. Sedangkan bagi orang yang mampu di segi ekonomi, tetapi keinginan kawin tidak begitu mendesak, ia boleh saja menunda perkawinannya, namun kawin tetap lebih baik guna melaksanakan Sunnah.

Mengingat adanya perbedaan kemampuan dalam melaksanakan perkawinan dan perbedaan kebutuhan terhadap perkawinan, maka klasifikasi hukum kawin tidak sama, sesuai dengan keadaan masing-masing orang orang. Sayyid Sabiq menyebutkan lima macam hukum kawin, yaitu:

a. Wajib, bagi orang yang mampu kawin dan nafsunya telah mendesak dan takut terjerumus ke dalam perzinaan wajiblah atasnya kawin. Menjauhkan diri dari yang haram adalah wajib, sedangkan hal itu tidak bisa dilakukan kecuali dengan jalan kawin.

b. Sunat. Bagi orang yang nafsunya mendesak dan mampu kawin, tetapi masih sanggup menahan diri dari berzina, maka baginya sunat hukumnya kawin. Kawin baginya lebih utama daripada tekun beribadah.

c. Haram. Bagi seseorang yang tidak mampu memenuhi nafkah lahir dan batin istri serta nafsunya tidak mendesak, haramlah ia kawin.

d. Makruh. Makruh kawin bagi seseorang yang lemah syahwat dan tidak mampu membelanjai istri, walaupun tidak merugikan istri kaya misalnya.

e. Mubah. Bagi laki-laki yang tidak terdesak oleh alasan-alasan yang mewajibkan kawin atau karena alasan-alasan yang mengharamkan kawin, maka hukum kawin baginya mubah. ${ }^{14}$

Ibnu Rusyd menerangkan, segolongan fukaha, yakni jumhur berpendapat nikah itu hukumnya sunat. Golongan ulama Zahiri berpendapat nikah itu hukumnya wajib. Para ulama Maliki mutaakhirin berpendapat nikah itu wajib untuk sebagian orang, sunat untuk sebagian lainnya dan mubah untuk sebagian lain lagi. Yang demikian itu ditinjau berdasarkan kemaslahatan dan kekhawatiran terdapat kesusahan. ${ }^{15}$

Adanya variasi hukum perkawinan sesuai dengan kondisi dan kemampuan orang yang melangsungkan perkawinan. Meskipun demikian,

\footnotetext{
${ }^{14}$ Sayyid Sabiq, Op. cit, hlm. 22-24.

${ }^{15}$ Ibnu Rusyd, Bidayatul Mujtabid, Jilid 3, (Jakarta: Pustaka Amani, 1995), hlm. 3.
} 
mengingat dasar hukum perkawinan sangat kuat, dan tujuannya sangat mulia, maka perkawinan mestilah dilestarikan dalam suatu masyarakat.

\section{Hukum Negara}

Perkawinan sebagai suatu ikatan yang kuat, dan agar terwujud perkawinan yang saling mengikat antarpasangan, maka selain harus disesuaikan dengan hukum agama, perkawinan seharusnya juga disesuaikan dengan hukum negara. Hukum Negara tersebut lebih mengatur kepada teknis pelaksanaan dan pencatatannya. Di Indonesia hukum perkawinan diatur melalui peraturan perundang-undangan di bidang perkawinan.

Bab I Pasal 2 Undang-Undang Nomor 1 Tahun 1974 tentang Perkawinan (selanjutnya disebut UPP) menyatakan: (1) Perkawinan adalah sah apabila dilakukan menurut hukum masingmasing agamanya dan kepercayaannya itu; (2) Tiap-tiap perkawinan dicatat menurut peraturan perundang-undangan yang berlaku.

Ketentuan ini sejalan dengan ketentuan $\mathrm{Bab}$ II Pasal 4, 5 dan 6 KHI sebagai berikut:

Pasal 4: Perkawinan adalah sah apabila dilakukan menurut hukum Islam sesuai pasal 2 ayat (1) Undang-Undang Nomor 1 Tahun 1974 tentang perkawinan;

Pasal 5: (1) Agar terjamin ketertiban perkawinan bagi masyarakat Islam setiap perkawinan harus dicatat; (2) Pencatatan perkawinan tersebut pada ayat (1) dilakukan oleh Pegawai Pencatat Nikah sebagaimana yang diatur dalam Undang-Undang Nomor 22 Tahun 1946 jo Undang-Undang Nomor 32 Tahun 1954.

Pasal 6: (1) Untuk memenuhi ketentuan dalam pasal 5, setiap perkawinan harus dilangsungkan di bawah pengawasan Pegawai Pencatat Nikah. (2) Perkawinan yang dilakukan di luar pengawasan Pegawai Pencatat Nikah tidak mempunyai kekuatan hukum.

Perkawinan memiliki kekuatan hukum dan ikatan kuat jika sudah menuruti aturan hukum Islam, dan bersamaan dengan itu juga menuruti ketentuan peraturan perundang-undangan yang berlaku di negara di mana perkawinan itu dilangsungkan. Perkawinan demikian tidak mudah diabaikan, diceraikan, atau tidak diakui oleh salah satu pihak. Perkawinan demikian menjamin kewajibankewajiban dan hak-hak suami dan istri secara seimbang dan proporsional, serta terjaminnya hak-hak anak-anak. Perkawinan yang dicatat secara resmi dengan dokumen yang sah oleh lembaga yang berwenang dapat dijadikan bukti hukum yang otentik apabila keluarga yang bersangkutan mengalami permasalahan di kemudian hari dan ingin diselesaikan melalui jalur atau lembaga hukum, misalnya bagi yang beragama Islam melalui Pengadilan Agama.

\section{Kawin Sirri \\ Arti dan Klasifikasi}

Dalam praktik pernikahan di kalangan umat Islam, akad nikah yang dilangsungkan itu ada yang dicatat oleh Kantor Urusan Agama (KUA), ada pula yang tidak. Dari sinilah kemudian berkembang istilah nikah sirri atau nikah di bawah tangan:

Di samping perkawinan yang dicatat secara resmi, ada pula perkawinan yang disembunyikan, yang diistilahkan dengan perkawinan sirri. Pada mulanya perkawinan sirri ini adalah perkawinan yang tidak memenuhi syarat dan rukun. Syaikhul Islam Ibnu Taimiyah pernah ditanya orang yang menikah secara mushafahah, yakni nikah sirri atau nikah tanpa wali dan tanpa saksi dengan maskawin 5 dinar, dan dia telah tinggal bersamanya dan mencampurinya. Apakah perkawinan itu sah, maka Ibnu Taimiyah mengatakan nikahnya batil atau tidak sah. ${ }^{16}$

Perkembangan selanjutnya nikah sirri tidak lagi dimaksudkan demikian. Berkaitan dengan hal ini Neng Zubaedah menerangkan: Pada awalnya pengertian nikah sirri itu ditujukan atau dimaknai terhadap perkawinan yang tidak memenuhi rukun dan syarat perkawinan. Sebagaimana dikemukakan oleh Umar bin Khattab ketika beliau menerima pengaduan perkara tentang perkawinan yang hanya disaksikan oleh seorang saksi laki-laki dan seornag saksi perempuan. Namun saat ini pengertian nikah sirri diperluas, yaitu perkawinan yang memenuhi rukun dan syarat perkawinan, tetapi belum/ tidak dicatatkan di Kantor Urusan Agama (KUA) Kecamatan bagi yang beragama Islam. Dengan demikian perkawinan yang memenuhi syarat dan rukun perkawinan menurut hukum Islam, namun belum/tidak dicatat disebut dengan nikah sirri. ${ }^{17}$

Abd. Shomad menerangkan, perkawinan sirri artau perkawinan di bawah tangan adalah perkawinan yang dilaksanakan dengan tidak

\footnotetext{
16 Ibnu Taimiyah, Hukum-Hukum Perkawinan, Alih bahasa Rusnan Yahya, (Jakarta: Pustaka al-Kautsar, 1997), hlm. 10.

${ }^{17}$ Neng Zubaedah, Pencatatan Perkawinan \&o Perkawinan Tidak Dicatat, (Jakarta: Sinar Grafika, 2010), hlm. 345.
} 
memenuhi syarat dan prosedur peratura perundangundangan. Menurut hukum Islam perkawinan sirri atau di bawah tangan adalah sah, asalkan telah terpenuhi syarat dan rukun perkawinan. Namun dari aspek perundang-undangan perkawinan model ini belum lengkap karena belum dicatatkan. Namun pencatatan itu hanya merupakan perbuatan administratif yang tidak berpengaruh terhadap sah tidaknya perkawinan. ${ }^{18}$

Rukun dan syarat perkawinan tersebut adalah:

1. Rukun perkawinan ada lima, yaitu adanya mempelai laki-laki, mempelai perempuan, adanya wali, dua orang saksi dan sighat (ijab qabul).

2. Syarat perkawinan meliputi:

a. Syarat suami: bukan mahram dari calon istri, atas kemauan sendiri/ tidak terpaksa, jelas orangnya, tidak sedang ihram haji.

b. Syarat istri: tidak ada halangan syar'i, maksudnya tidak sedang bersuami, bukan mahram, tidak sedang beriddah;

c. Syarat wali: laki-laki, baligh, berakal, tidak dipaksa, adil dan tidak sedang ihram haji;

d. Syarat saksi: laki-laki, baligh, berakal, adil, dapat mendengar dan melihat, bebas. tidak terpaksa, memahami bahasa yang digunakan dalam ijab qabul dan tidak sedang ihram haji. ${ }^{19}$

Perkawinan sirri tetap memenuhi rukun dan syarat yang disebutkan di atas, namun tidak dicatat atau perkawinannya disembunyikan. Hal ini bisa terjadi karena:

1. Dalam rangka perkawinan poligami, sementara persyaratan poligami yang harus dipenuhi oleh suami secara tercatat sangat ketat;

2. Bukan dalam rangka poligami, tetapi dilakukan oleh orang-orang tertentu yang terikat dengan perjanjian dalam bidang pekerjaannnya yang mengharuskan dia menunda atau tidak melangsungkan perkawinan dalam jangka waktu tertentu.

3. Dalam rangka kawin gantung yang dahulu banyak dilakukan oleh masyarakat namun sekarang sudah berkurang.

Perkawinan demikian sah, sepanjang tidak

\footnotetext{
18 Abd. Shomad, Hukum Islam Penormaan Prinsip Syariah dalam Hukum Indonesia, (Jakarta: Prenada Media Group, 2010), hlm. 208.

${ }^{19}$ Al-Hamdani, Op. cit., hlm. 30-31.
}

dimaksudkan untuk melecehkan dan merendahkan istri dan menelantarkan anak-anak yang akan dilahirkan. Juga ada keinginan untuk mencatat perkawinannya jika syarat-syaratnya sudah terpenuhi. ${ }^{20}$

Wildan Mustofa membagi nikah sirri dalam dua golongan. Pertama akad nikah dilakukan oleh seorang laki-laki dan seorang perempuan tanpa hadirnya orang tua/wali si perempuan. Nikahnya hanya dihadiri oleh laki-laki dan perempuan yang melakukan akad nikah, dua orang saksi, dan guru atau ulama yang menikahkan, tanpa memperoleh pendelegasian dari wali nikah yang berhak. Kedua, akad nikah yang telah memenuhi syarat dan rukun perkawinan yang legal sesuai ketentuan hukum Islam, tetapi tidak dicatatkan sesuai kehendak undang-undang perkawinan di Indonesia. ${ }^{21}$

Meskipun nikah sirri dianggap sah, ada pula kalangan ulama mazhab yang tidak membolehkannya. M Anshari MK mengatakan: Nikah sirri artinya nikah rahasia, lazim disebut dengan nikah di bawah tangan atau nikah liar. Dalam fikih Maliki nikah sirri diartikan sebagai nikah yang atas pesan suami para saksi merahasiakannya untuk istrinya, atau jamaahnya sekalipun keluarga setempat. Mazhab Maliki tidak membolehkan nikah sirri, nikah ini dapat dibatalkan dan pelakunya dapat dihukum badd. Mazhab Syafi'i dan Hanafi juga tidak membolehkan nikah sirri. Khalifah Umar pernah mengancam orang yang menikah sirri dengan hukuman hadd. ${ }^{22}$

Dari beberapa pendapat di atas dapatlah disimpulkan bahwa nikah sirri adalah nikah yang dilakukan tidak secara resmi, tidak menurut peraturan perundang-undangan yang berlaku, dan agak tertutup dalam pelaksanaannya. Nikah sirri dapat dibagi dua. Pertama, nikah yang memenuhi rukun dan syarat pernikahan, namun karena satu dan lain hal, tidak dicatat menurut peraturan perundang-undangan. Nikah demikian menurut pendapat kebanyakan ulama dan ahli hukumnya sah. Keabsahan tersebut alangkah baiknya kelak diperkuat dengan mengurus pencatatannya sesuai peraturan perundang-undangan yang berlaku, sehingga memiliki dokumen pernikahan yang otentik. Kedua, nikah yang dilakukan tanpa terpenuhi salah satu atau beberapa rukun dan

\footnotetext{
${ }^{20}$ Neng Zubaedah, Loc cit.

${ }_{21}$ M. Anshari MK, Hukum Perkawinan di Indonesia Masalahmasalah Krusial, (Yogyakarta: Pustaka Pelajar, 2010), hlm. 24.

${ }^{22}$ Ibid., hlm. 25-26.
} 
syaratnya, misalnya tidak ada wali, dan juga dilakukan secara rahasia. Pernikahan demikian, menurut sebagian ulama, terutama mazhab Hanafi, Maliki dan Syafi'i tidak sah. Namun ada juga ulama yang membolehkannya dalam kondisi darurat.

\section{Kawin Sirri di Masyarakat}

Fenomena nikah sirri, baik dalam golongan pertama, maupun kedua, banyak sekali terjadi di masyarakat. Hal ini dapat diuraikan sebagai berikut:

\section{Golongan pertama}

Golongan pertama ini menikah secara sirri dengan memenuhi semua rukun dan syarat pernikahan, dalam arti ada wali yang berhak menikahkan, ada kedua suami istri yang menikah, ada saksi yang adil, dan ada akad (ijab-qabul) pernikahan. Banyak sekali contoh orang yang melakukan hal-hal seperti ini. Di kalangan tokoh/ pejabat misalnya perkawinan Moerdiono dengan artis Machica Muchtar. Di kalangan artis misalnya dapat disebut perkawinan Rhoma Irama dengan beberapa istrinya, perkawinan Ahmad Dhani dengan Mulan Jameelah, perkawinan Farhat Abbas dengan Regina dan sebagainya.

Di kalangan ustadz populer diantaranya perkawinan Ustadz Aswan dengan Rima Idris., dan masih banyak lagi yang lainnya.

Mereka yang melangsungkan nikah sirri di atas, sampai artikel ini ditulis, ada yang rumah tangganya bisa langgeng, namun ada juga yang bermasalah, dalam arti dipermasalahkan oleh istri pertamanya, istri keduanya atau oleh suami itu sendiri.

Kebanyakan nikah sirri model di atas dilakukan dalam rangka poligami, dan hal ini banyak sekali terjadi di masyarakat. Atau karena status salah satu pasangan, calon istri atau calon suami bercerai di bawah tangan sehingga tidak ada bukti tertulis perceraiannya, yang berakibat mereka terpaksa menikah secara sirri.

Ada pula pernikahan sirri dilakukan karena sengaja ingin mengesahkan pernikahan saja secara agama, di mana ayah atau walinya bertindak sebagai wali yang sah, agar kedua pasangan halal bergaul sebagai suami istri. Pasangan ini belum mencatatkan pernikahannya sambil menunggu waktu yang tepat.

\section{Golongan kedua}

Nikah sirri dalam praktik yang terjadi di tengah masyarakat, banyak dalam bentuk kedua, yaitu menikah secara sirri karena tidak ada wali, dengan tidak menggunakan prosedur wali hakim. Dalam hal ini pasangan suami istri atau para pihak yang terlibat dalam pernikahan tersebut menggunakan wali mubakkam, bukan wali nasab (ayah, kakek, saudara kandung, saudara seayah dan seterusnya) dan wali hakim (pejabat pemerintah yang ditunjuk) sebagaimana diatur dalam agama dan peraturan yang berlaku.

Abdul Qadir Syukur dalam tesisnya tentang pernikahan dengan Wali muhakkam, akibat hukum dan solusinya, ${ }^{23}$ serta Kasyful Anwar dalam penelitiannya tentang nikah sirri melalui wali muhakkam, ${ }^{24}$ membahas mengenai maksud dan kedudukan wali muhakkam lebih terperinci. Kata mubakkam diambil dari bahasa Arab yang asal katanya bak.kama-yubak.kimu -tabkiiman - mubuk.kimun - mubakeamun, yang artinya memegang perintah, mengepalai, menghukumkan, menjatuhkan hukum. ${ }^{25}$ Mabkamatun artinya tempat berhakim. ${ }^{26}$ Menurut kaidah ilmu tashrif, kata bakama adalah timbangan (wazan) fa'ala yang diubah menjadi wazan fa'ala, sehingga kata bakama berubah menjadi hakama-yabkumu-tabkiman. Kata tabkim dalam bahasa Indonesia yang berarti mengangkat hakim, menjadikan hakim. ${ }^{27}$

Dimaksud wali muhakkam dalam perkawinan ialah seseorang yang diangkat oleh kedua calon suami isteri untuk bertindak sebagai wali dalam akad nikah mereka. Apabila suatu pernikahan yang seharusnya dilaksanakan dengan wali hakim, padahal tempat itu tidak ada wali hakimnya, maka pernikahan dilangsungkan dengan wali muhakkam. Caranya ialah kedua calon suami istri mengangkat seorang yang mempunyai pengertian tentang hukum-hukum agama untuk menjadi wali dalam pernikahan mereka. ${ }^{28}$

Jadi, jika pernikahan tidak dapat menghadirkan wali nasab, dan tidak pula dapat dilakukan dengan

${ }^{23}$ Lihat Abdul Qadir Syukur, Wali Mubakkam dalam Pernikahan, Akibat Hukum dan Solusi, Tesis, (Banjarmasin: Pascasarjana IAIN Antasari, 2012).

${ }^{24}$ Lihat Kasful Anwar, Nikah Sirri Melalui Wali Mubakkam di Kecamatan Tanjung Kabupaten Tabalong", Skripsi, (Amuntai: STAI Rakha, 2014).

25 Muhammad Idris al-Marbawi, Kamus al-Marbawi, (Surabaya: Dar al-Ihya, tth), hlm. 142.

${ }^{26}$ Ibid., hlm. 143.

${ }^{27}$ Departemen P \& K RI, Kamus Besar Bahasa Indonesia, (Jakarta: Balai Pustaka, 1990), hlm. 884.

28 Departemen Agama, Pedoman Pembantu Pegawai Pencatat Nikah, (Jakarta: Badan Pembantu Kesejahteraan Masjid, 1991-1992), hlm. 53. 
wali hakim, karena wali hakimnya tidak ada di tempat pernikahan itu dilaksanakan, maka dalam keadaan demikian, pernikahan boleh dengan menggunakan wali muhakkam. Keadaan yang membolehkan dilaksanakannya pernikahan dengan wali muhakkam diterangkan sebagai berikut:

Dalam hubungan ini Malik berkata tentang perempuan yang kondisinya lemah, ia boleh dikawinkan oleh orang yang diserahi urusannnya, karena ia tidak dapat pergi kepada sultan. Jadi seolaholah sultan tidak berada di tempatnya, sehingga seluruh orang Islam secara umum dapat bertindak sebagai walinya. Syafi'i berpendapat bahwa apabila dalam masyarakat terdapat perempuan yang tidak mempunyai wali, lalu ia mewalikannya kepada seorang laki-laki untuk menikahkannya, maka hukumnya boleh. Karena hal itu merupakan tindakan yang mengangkat hakim. Dan orang yang diangkat sebagai hakim sama kedudukannya dengan hakim itu sendiri. ${ }^{29}$

Qurthubi berkata: Jika perempuan yang tinggal di tempat yang tak ada sultan dan tidak ada pula mempunyai wali, maka penyelesaiannya dapat, ia serahkan kepada tetangga yang dipercayainya untuk mengakadkannya. Dalam keadaan demikian tetangga tersebut telah menjadi wali. Karena setiap orang tentu perlu kawin, tetapi dalam melaksanakannya hendaklah sebaik-baiknya yang dapat dikerjakan.

Al-Imam Taqiyuddin al-Hushaini al-Dimasyqi mengatakan, Yunus bin Al Imam Al Husaini meriwayatkan dari Syafi'i bahwa jika dalam suatu masyarakat ada seorang wanita yang tidak memiliki wali sama sekali, lalu ia menguasakan atau mewakilkan perkaranya kepada seorang laki-laki, termasuk dalam hal pernikahan, maka hukumnya boleh. Sebab hal itu termasuk pelimpahan kekuasaan dan status orang yang dilimpahi kekuasaan itu sama seperti hakim.

Imam al-Nawawi mengatakan, menurut al-Mawardi jika seorang wanita tidak punya wali sama sekali, maka ia memiliki tiga pilihan. Pertama, ia tidak menikah. Kedua, ia bisa menikahkan dirinya sendiri karena alasan darurat. Ketiga, ia bisa menguasakan/ menyerahkan urusannya kepada seseorang, kemudian orang itulah yang menikahkannya. ${ }^{30}$

\footnotetext{
${ }^{29}$ Sayyid Sabiq, Op. cit., hlm. 27.

${ }^{30}$ Syaikh Muhammad Hafizh Ali al-Syuwaisyi, Tubfah alUrusy wa bi Hajah al-Nufus, Alih bahasa Abdul Rosyad Shiddiq, Kado Pernikahan, Jakarta; Pustaka al-Kautsar,
}

Al-Syuwaisyi mengatakan, bahwa dalam masalah seorang wanita tidak mempunyai wali sama sekali, ia boleh menguasakan kepada seorang ulama fikih yang ahli ijtihad. Pelimpahan kekuasaan seperti itu hukumnya sah, sehingga pernikahannya pun boleh. Tetapi dengan syarat pihak yang dilimpahi kekuasaan tersebut harus orang yang memang patut untuk memberikan keputusan, dan ini cukup sulit untuk ditemuka di zaman sekarang. Menurut pendapat yang kita pilih, pernikahannya sah apabila ia menyerahkan urusannya kepada orang yang adil (terjaga kehormatan dan dirinya), walaupun tidak sampai sebagai mujtahid. Itulah pendapat yang dikutip oleh Yunus bin Abdul A'la, seorang ulama yang jujur. ${ }^{31}$

Usman Abdullah al-Husaini dalam al-Qawanin al-Syariyyah menyatakan masalah nikah dengan wali muhakkam ini, yang kutipan aslinya berbahasa Arab Melayu, sebagai berikut: Adapun jikalau tiada sekalikali ada wali atau gaib dua marhalah yaitu sembilan puluh pal atau dibawa tiada baulibi orang bertemu padanya atau wali itu 'adhal yakni enggan daripada menikahkan atau bersembunyi maka suatu daripada lima hal ini maka jikalau ada qadhi syar'i maka ialah yang menikahkan. Adapun jikalau tiada qadhi maka bertahkim daripadanya. Tetapi wajib diperiksa lebih dahulu akan walinya adanya sama tiadanya. Dan dekatnya sama jauhnya, hadirnya sama ghaibnya. Maka jikalau sudah sungguh-sungguh tiada walinya atau ghaibnya dua marhalah yaitu sembilan puluh pal dan tiada qadhi syar'i, maka itu waktulah bertahkim. ${ }^{32}$

Melihat beberapa pendapat di atas tampaknya wali muhakkam dalam pernikahan sirri dibolehkan bila seorang perempuan tidak memiliki wali sama sekali, walinya ghaib dalam jarak dua marhalah dan di daerah setempat tidak ada qadhi syar'i (hakim). Hal itu dilakukan setelah lebih dahulu diadakan penelitian secara seksama tentang keberadaan wali nasabnya. Sedangkan dalam pernikahan resmi tidak dikenal adanya wali muhakkam, karena yang dibenarkan sebagai wali hanyalah wali nasab dan wali hakim.

Tetapi mengingat sekarang ini khususnya di Kalimantan Selatan, boleh dikatakan di semua

2005), hlm. 51-52.

31 Ibid., hlm. 52.

${ }^{32}$ Usman bin Abdullah bin Aqil bin Yahya al-Alawi alHushaini, al-Qawanin al-Syariah Majalis al-Hukmiyyah wa al-Iftaiyyah, (Surabaya: Syirkah Maktabah wa al-Mathba'ah Salim Nabhan wa Auladuh, tth), hlm. 60-61. 
tempat sudah tersedia wali hakim (Kepala Kantor Agama atau petugas yang ditunjuk), maka wali muhakkam tidak berlaku lagi. Dengan begitu nikah sirri dengan menggunakan wali muhakkam boleh dikatakan tidak sah. Mereka ini seharusnya menggunakan wali hakim.

Hal ini sejalan pula dengan pendapat ulama di Kota Banjarmasin yang diwawancarai oleh Abdul Qadir Syukur, yaitu Drs. KH Adenani Iskandar (alm), Drs. H. Ibrahim Hasani, Drs.H. Humaidi Dahlan, Lc, Drs. H. Tabrani Basri, H. Junaidi As Khalid dan Drs. H. Karsayudha, SH, M.Ag. (alm). Ternyata hampir semua ulama ini berpendapat pernikahan sirri melalui wali muhakkam tidak sah. Hal ini karena menurut mereka hanya sultan (pemerintah) yang berwenang bertindak sebagai wali hakim bagi wanita yang tidak memiliki wali, wali jauh, wali berbeda agama atau wali tidak merestuinya (adhal). Orang di luar sultan tidak memiliki hak melakukannya. Kondisi darurat sebagai celah hukum untuk menikah dengan wali muhakkam kurang terpenuhi, sebab para pihak tersebut tidak melakukan usaha maksimal untuk menikah secara resmi.

\section{Akibat Hukum}

Nikah sirri golongan pertama bisa saja dianggap sah. Begitu juga nikah sirri golongan kedua, dengan alasan darurat, mungkin juga ada ulama yang menganggap dibolehkan. Tetapi dengan statusnya sebagai nikah sirri, maka yang tidak bisa dihindari adalah akibat hukumnya yang sama-sama merugikan. Nikah sirri karena tidak dikuatkan oleh dokumen yang sah, maka mudah sekali dilepaskan dan diabaikan. Suami gampang sekali mencerai atau tidak memenuhi kewajibannya terhadap istri, dan istri akan kesulitan menuntut hak-haknya karena tidak ada bukti sah tentang perkawinan tersebut. Dalam perkawinan poligami di mana kawin sirri banyak terjadi, suami atau istri tua dan anakanaknya juga gampang menganggap perkawinan sirri itu tidak ada. Akibatnya masalah menjadi sangat kompleks dan sulit untuk diselesaikan bahkan sampai ada di antara para pihak meninggal dunia.

Misalnya kasus yang menimpa Machica Muchtar dan anaknya, mereka sampai harus melakukan tes DNA (Deoxyribo Nucleic Acid) untuk membuktikan bahwa perkawinan itu memang ada. Ternyata hasil tes DNA yang dilakukan oleh RSCM Jakarta menyatakan bahwa Muhammad
Iqbal (17) memang anak kandung alm Moerdiono bersama artis senior Machica Muchtar.

Tes DNA adalah salah satu cara untuk memastikan bukti hubungan darah antara anak dengan kedua orang tua kandungnya, yang untuk kasus ini tingkat akurasinya mencapai 99,99 persen. Hal ini sangat melegakan bagi Machica yang sudah sekian lama menuntut pengakuan keluarga Moerdino atas status hukum anaknya. Tetapi dari keluarga alm Moerdiono tidak ada yang bersedia melakukan tes yang sama. Untuk itu pihak Pengadilan akan melakukan penambahan alat bukti, yaitu sumpah supletoir, yang artinya sumpah tambahan dari Machica sebagai penggugat, sehingga majelis hakim semakin yakin dalam mengeluarkan putusannya.

Sumpah supletoir identik dengan sumpah pocong (mubahalab), di mana yang bersumpah bersaksi atas nama Allah akan kebenaran sumpahnya dan berani menanggung risiko dilaknat oleh Allah jika pernyataannya tidak benar. Merasa benar Machica pun sudah disumpah dengan cara ini. Tetapi tetap saja ia tidak berhasil menuntut haknya dan hak anaknya secara layak. ${ }^{33}$

Dalam kasus Ustadz Aswan dan istri mudanya yang dinikahi secara sirri lain lagi. Semula ia menjanjikan kepada istri keduanya yang dinikahi secara sirri tersebut, akan dinikahi secara resmi. Tetapi ketika janji ini ditagih, justru si istri diceraikan, juga secara tidak resmi. Hal ini berakibat si istri kesulitan menuntut hak-haknya, juga hakhak anaknya. Terabaikannya hak istri tersebut bisa berlanjut sampai kepada kewarisan apabila suami meninggal lebih dahulu.

Belum lagi urusan bepergian, menginap di hotel tertentu yang mensyaratkan buku nikah, pembuatan paspor dan sebagainya, buku nikah sebagai bukti nikah resmi menjadi sangat penting. Akibat lainnya akan menimpa anak yang lahir dari perkawinan sirri tersebut. Anak akan kesulitan mendapatkan akta kelahiran, sebab salah satu persyaratannya adalah adanya buku nikah.

Alasan filosofis, administasi dan hukum bahwa perkawinan harus dicatat oleh lembaga resmi adalah karena perkawinan merupakan lembaga suci dan berkekuatan hukum, dengan perkawinan akan memberikan kejelasan status dan kedudukan anak yang dilahirkan. Asal usul kelahiran seseorang

\footnotetext{
33 Sumpah Suplitoir Machica Muchtar, Banjarmasin Post, 5 Maret 2013.
} 
tentunya sangat menentukan kehidupannya kelak, seperti halnya dengan status apakah dia terlahir sebagai anak sah atau anak di luar kawin. Perbedaan status akan membedakan hak dan kedudukan anak sah dan anak luar kawin.

Menurut Ida Chairiaty, asal usul kelahiran anak dapat dilihat dalam akta kelahiran mereka. Adanya akta kelahiran dimaksudkan agar seorang anak dapat membuktikan bahwa dirinya adalah benarbenar anak yang sah dari ayah dan ibunya. Jika asal usul seorang anak tidak dilindungi oleh hukum, atau dengan kata lain anak tersebut tidak memiliki akta kelahiran, maka jika kelak anak tersebut ingin melakukan perbuatan hukum tertentu, misalnya menuntut harta warisan orang tuanya maka anak tersebut akan mengalami kesulitan. Sebab secara hukum tidak dapat membuktikan bahwa ia adalah anak kandung dari orang tua yang meninggalkan harta warisan. Lain halnya dengan anak yang memiliki akta kelahiran, ia akan lebih mudah membuktikan tentang asal usul kelahirannya. Tegasnya setiap kelahiran itu perlu memiliki bukti tetulis dan otentik karena untuk dapat membuktikan identitas seseorang yang pasti dan mempunyai kekuatan pembuktian yang sempurna dapat dilihat dari akta kelahiran yang dikeluarkan oleh suatu lembaga yang berwenang untuk mengeluarkan akta tersebut. $^{34}$

Di Indonesia yang berhak mengeluarkan akta kelahiran adalah Lembaga Catatan Sipil yang diatur dalam Peraturan Presiden Nomor 25 Tahun 2008 tentang Persyaratan Tata Cara Pendaftaran Penduduk dan Pencatatan Sipil. Setelah ditetapkan Perturan Presiden tersebut maka setiap peristiwa kelahiran yang terjadi di tengah-tengah masyarakat perlu didaftarkan di Dinas Kependudukan dan Pencatatan Sipil guna mendapatkan akta kelahiran.

Dinas Kependudukan dan Pencatatan Sipil Kota Banjarmasin merupakan salah satu lembaga teknis daerah di lingkungan Pemerintah Kota Banjarmasin, yang berdasarkan Peraturan Daerah Nomor 15 Tahun 2008 tentang Susunan Organisasi dan Tata Kerja Sekretariat Daerah, Sekretariat Dewan Perwakilan Rakyat Daerah, Dinas, Badan, Kecamatan dan Kelurahan Kota Banjarmasin

\footnotetext{
${ }^{34}$ Ida Chairiaty, Implementasi Kebijakan Program Pelayanan Akta Kelabiran Gratis di Kota Banjarmasin (Studi Kasus Program Dispensasi Penerbitan Akta Kelabiran di Atas 1 (Satu) Tabun Tanpa Penetapan Pengadilan), Tesis, (Banjarmasin; Pascasarjana Univeritas Lambung Mangkurat, 2011), hlm. 5.
}

mempunyai Tugas Pokok melaksanakan urusan rumah tangga daerah di bidang Kependudukan dan Pencatatan Sipil.

Sebagai bentuk kepedulian dan perwujudan tanggung jawab Pemerintah Kota Banjarmasin untuk memberikan akta kelahiran sebagaimana diamanatkan dalam Undang-Undang Nomor 23 Tahun 2002 tentang Perlindungan Anak dan Undang-Undang Nomor 23 Tahun 2006 tentang Administrasi Kependudukan serta untuk mendorong pencapaian Renstra 2011 bahwa "semua anak tercatat kelahirannya", dibuat kebijakan berupa Peraturan Daerah No. 11 Tahun 2008 tentang Penyelenggaraan Administrasi Kependudukan dan Pencatatan Sipil Kota Banjarmasin, serta Peraturan Daerah Nomor 12 Tahun 2009 tentang Retribusi Pelayanan di bidang Kependudukan dan Pencatatan Sipil serta pelayanan lainnya, di mana pada tarif retribusi ini untuk pelayanan akta kelahiran dinyatakan gratis atau tidak dipungut biaya. ${ }^{35}$

Namun menurut Komisi Perlindungan Anak Indonesia (KPAI) Provinsi Kalimantan Selatan, pada Tahun 2010 tercatat lebih dari 27 ribu anak usia 0-5 Tahun di Kota Banjarmasin tidak memiliki Akta Kelahiran, dari total jumlah anak-anak pada waktu itu sebanyak 58 ribu jiwa. Hal tersebut menandakan bahwa orang tua kurang memperhatikan hak sipil anak, dan mungkin pula dari sejumlah anak tersebut ada yang lahir dari perkawinan sirri, sehingga orangtuanya kesulitan untuk menguruskan akta kelahirannya.

Tetapi apa pun penyebabnya, yang jelas keadaan ini nantinya dikhawatirkan akan mempersulit anak dalam menempuh kehidupan mendatang seperti dalam hal pembagian hak waris, pendaftaran sekolah, pembuatan KTP, Kartu Keluarga dan lain sebagainya. Menurut hukum Islam, ada tiga hal yang menjadi sebab seseorang dapat mewarisi dari orang lain meninggal dunia, yaitu perkawinan; kekerabatan; dan wala'. ${ }^{36}$ Jadi, kalau status perkawinan orangtuanya bermasalah, maka sulitlah bagi anak untuk menuntut hakhaknya tersebut. Perkawinan yang dapat dijadikan alasan saling mewarisi adalah perkawinan yang sah menurut syariat, selama perkawinan itu masih berlangsung.

Memang sebenarnya Allah memberikan hak mewarisi tidak tergantung kepada status

\footnotetext{
35 Ibid., hlm. 6.

${ }^{36}$ Fatchur Rachman, Imu Waris, (Bandung: Alma'arif,, 1994), hlm. 24.
} 
sirri atau tidaknya pernikahan. Tetapi prosedur penyelesaian harta waris itu yang sulit ditempuh melalui pengadilan jika tidak dikuatkan oleh akta nikah. Sementara orangtua meninggalkan harta pusaka yang dapat diwarisi. Apabila hak waris anak terabaikan, maka hal itu bertentangan dengan Undang-Undang Nomor 4 Tahun 1979 tentang Kesejahteraan Anak. Pada Bab II Pasal 2 UndangUndang ini diterangkan: (1) Anak berhak atas kesejahteraan, perawatan, asuhan dan bimbingan berdasarkan kasih sayang, baik dalam keluarganya maupun dalam asuhan khusus untuk tumbuh dan berkembang secara wajar; (2) Anak berhak atas pelayanan untuk mengembangkan kemampuan dan kehidupan sosialnya sesuai dengan aturan negara yang baik dan berguna.

\section{Saadu乏 Ziraiyah}

Melihat akibat-akibat negatif nikah sirri di atas, baik akibat hukum, keluarga maupun sosial, maka lebih baik nikah sirri dihindari. Meskipun nikah sirri, khususnya golongan pertama sah secara agama, tetapi banyak dampak negatif yang ditimbulkannya. Nikah sirri demikian membuka jalan bagi terabaikannya hak-hak istri dan anak.

Adanya banyak implikasi demikian, berarti pernikahan sirri membawa mudharat, terutama bagi istri dan anak-anak di kemudian hari. Agama tidak menghendaki kemudaratan demikian, hanya karena kepentingan sesaat, yaitu ingin menikah secara instan. Sebuah kaidah fikih menyatakan: Menghindari keburukan hendaknya didabulukan daripada menarik kemanfaatan. ${ }^{37}$

Meksipun nikah sirri sering dilakukan karena alasan darurat, terpaksa, menghindari zina dan sebagainya, namun alasan ini tidak tepat. Perzinaan sebagai perbuatan terkutuk dan berdosa besar harus dihindari, tetapi cara menghindarinya tentu bukan dengan melakukan pelanggaran baru. Memang bisa saja dipakai kaidah fikih: idza ta'aradha dhararani fuddbila akbaffubuma (jika ada dua bahaya/risiko, maka dahulukan bahaya yang lebih ringan). ${ }^{38}$ Maksudnya daripada pasangan berbuat zina sebagai suatu pelanggaran hukum lebih baik dilakukan pernikahan sirri yang juga melanggar hukum. Tetapi menghilangkan suatu bahaya tidak boleh dengan melakukan bahaya lainnya. Kaidah fikih

\footnotetext{
${ }^{37}$ Masyfuk Zuhdi, Masail Fiqhiyah, (Jakarta: Haji Masagung, 1996) hlm. 158.

${ }^{38}$ Ibid., hlm. 137.
}

menyatakan: al-dhararu la yuzalu bi al-dharara (bahaya tidak boleh dihilangkan dengan bahaya lainnya). ${ }^{39}$

Menghindari zina tetapi dengan melakukan pernikahan yang kontroversial dan diragukan keabsahannya, banyak implikasinya yang merugikan, tidak sejalan dengan tujuan perkawinan untuk mewujudkan kemaslahatan dan kebahagiaan suami istri dan keturunannya. Langkah begini dapat dilakukan dalam kondisi yang benar-benar darurat, sedangkan dalam kasus-kasus yang terjadi di masyarakat kelihatannya belum begitu darurat. Masih ada peluang usaha lain, namun peluang itu sengaja tidak dilakukan atau dihindari oleh pemuka agama yang menikahkan dan pasangan yang menikah. Sekiranya sudah diusahakan maksimal tetap gagal menikah, baru boleh dikatakan sudah darurat.

Di masa lalu ketika hakim masih langka, misalnya orang tinggal di hutan, di laut atau tempattempat yang terisolasi yang tidak ada hakimnya, bisa saja nikah sirri golongan kedua (dengan melalui wali muhakkam) dibolehkan. Qurthubi mengatakan, jika perempuan tinggal di tempat yang tidak ada sultannya dan tidak pula mempunyai wali, maka penyelesaiannya dapat ia serahkan kepada orang yang dipercayainya untuk mengakadkannya. Dalam keadaan demikian orang tersebut telah bertindak sebagai wali, karena setiap orang tentu perlu kawin tetapi dalam melaksanakan hendaknya dilakukan sebaik-baiknya yang dapat dikerjakan. ${ }^{40}$

Jadi kebolehan secara sirri hanya dalam keadaan tertentu. Dalam keadaan demikianlah para ulama terdahulu membolehkan. Sekarang, dengan sudah tersebarnya sultan (wali hakim) di manamana, maka kebolehan itu bisa saja tidak berlaku. Dalam hukum Islam, aturan hukum bisa saja berubah sejalan dengan perubahan zaman. Kaidah fikih menyatakan: taghayyur al-abkâm bi taghayyuri alazminati wa al-amkinati wa al-abwali (hukum-hukum itu bisa berubah karena perubahan zaman, tempat dan keadaan). ${ }^{41}$

Pemerintah sebagai sultan atau hakim telah pula melarang menikah secara sirri atau menikah melalui wali muhakkam, mestinya tidak ada perbedaan pendapat lagi karena ketentuan penguasa itu berfungsi menghilangkan ikhtilaf. Kaidah Fikih berbunyi: bukmu al-hâkimi ilzamun wa yarfa'u alkhilâf (keputusan pemerintah itu mengikat untuk

${ }^{39}$ Ibid., hlm. 88.

${ }^{40}$ Sayyid Sabiq, Loc. cit.

${ }^{41}$ Masyfuk Zuhdi, Op. cit., hlm. 183. 
dilaksanakan dan menghilangkan perbedaaan pendapat). ${ }^{42}$

Pemuka agama yang biasanya terlibat dalam pernikahan sirri perlu berusaha untuk keluar dari melakukan hal-hal yang bersifat ikhtilaf supaya perbuatannya tidak menjadi kontroversi bahkan mengandung konsekuensi hukum, karena sudah ada ketentuan hukum yang satu. Bukan mencaricari alasan untuk melakukan ikhtilaf. Kaidah fikih menyatakan: al-kburûju min al-kbilâfi mustahabbun (menghindari perbedaan pendapat itu disunatkan. ${ }^{43}$ Di dalam hadits dinyatakan pula yang artinya: Dari Anas ra dari Nabi saw belian bersabda: Tinggalkan apa yang meragukanmu dan lakukan apa yang tidak. meragukanmu (HR Ahmad). ${ }^{44}$

\section{Penutup}

Dapat ditegaskan, pernikahan sirri sangat diragukan keabsahan dan kekuatan hukumnya baik menurut hukum Islam apalagi menurut Hukum Positif. Dasar dan alasan-alasan yang selama ini dipergunakan, baik dasar agama maupun pertimbangan keadaan darurat masih sangat lemah dan tidak dapat dipertanggungjawabkan.

Banyak pasangan yang menikah secara sirri selama ini umumnya berstatus duda atau janda, atau karena motif poligami, mereka hanya ingin serba mudah, praktis dan agar cepat berkumpul sebagai suami istri. Tetapi sebenarnya hal ini mengandung banyak risiko. Terlepas dari status hukumnya, yang oleh sebagian ulama dibolehkan, namun pernikahan demikian terkesan sangat longgar. Tidak adanya buku nikah dapat membuat suami istri tersebut sangat mudah untuk bercerai nantinya. Belum lagi akibat yang merugikan anak-anak yang lahir dari perkawinan tersebut.

Dalam kehidupan rumah tangga hampir selalu terjadi masalah, besar atau kecil. Mereka yang menikah secara sirri, apalagi jika disertai kelemahan di segi ekonomi tentu rentan bertengkar dan berpisah. Mereka begitu mudah bercerai tanpa perlu lagi ke pengadilan. Sebab dari awal mereka sudah tidak melibatkan pengadilan dan KUA dalam urusan pernikahannya. Ini berarti pernikahan sirri cenderung mempermudah terjadinya perceraian,

\footnotetext{
42 Majelis Ulama Indonesia, Himpunan Fatwa MUI, (Jakarta: Departemen Agama RI, 2003), hlm. 173.

${ }^{43}$ Masyfuk Zuhdi, Op. cit., hlm. 138.

${ }^{44}$ al-Imam Jalaluddin Abdirrahman bin Abibakar alSuyuthi, al-Jami' al-Shaghir, Juz 1, (Surabaya: Dar al-Ihya al-Kutub al-Arabiyah, tth), hlm. 15.
}

padahal perceraian merupakan perbuatan halal yang dibenci oleh Allah swt. sebagaimana hadis yang artinya: Dari Ibn Umar dari Nabi saw beliau bersabda: Perbuatan halal yang dibenci di sisi Allah adalah thalaq (HR. Abi Daud). ${ }^{45}$

Hak dan kewajiban suami istri yang jika menikah secara resmi akan dijamin oleh undang-undang dan mendapatkan pengakuan di masyarakat. Mereka selain mendapatkan buku nikah, biasanya juga mengucapkan ikrar sighat taklik untuk melindungi hak-hak istri, baik berkaitan dengan kebutuhan jasmani maupun rohani. Juga diberikan nasihatnasihat perkawinan dan buku-buku pedoman untuk membentuk keluarga bahagia dan sejahtera yang resmi dari pemerintah, yang tidak dijual di pasaran. Ketiadaan buku nikah berarti undang-undang tidak bisa melindunginya sekiranya terjadi permasalahan. Jadi risiko pernikahan terpaksa ditanggung sendiri oleh pasangan yang menikah tersebut.

Pasangan yang menikah sirri cenderung hanya berpikir jangka pendek, mencari jalan pintas dan mencari mudahnya saja. Mereka tidak memikirkan risiko hukum atas tindakannya, baik menurut Hukum Islam maupun Hukum Positif dan tidak pula memikirkan prospek kehidupan pernikahannya dan anak-anaknya ke depan. Sekiranya memungkinkan, pasangan demikian hendaknya memperbaharui pernikahannya secara resmi di KUA, supaya memperoleh legitimasi sebagaimana mestinya.

\section{Daftar Pustaka}

Abdurrahman, Kompilasi Hukum Islam di Indonesia, (Jakarta: Akademika Pressindo, 1992).

al-Bukhari, Al Imam Abi Abdillah Muhammad bin Ismail bin Ibrahim, Shabih al-Bukhari, Jilid III, Juz 6, (Beirut: Dar al-Fikr, 1401 H).

al-Hushaini, Usman bin Abdullah bin Aqil bin Yahya al-Alawi, al-Qawanin al-Syariah Majalis al-Hukmiyyah wa al-Iftaiyyah, (Surabaya: Syirkah Maktabah wa al-Mathba'ah Salim Nabhan wa Auladuh, tth).

al-Marbawi, Muhammad Idris, Kamus al-Marbawi, (Surabaya: Dar al-Ihya, tth), h. 142.

al-Sijistani, al-Imam Abi Daud Sulaiman, Sunan Abi Daud, (Surabaya: Maktabah Dahlan, tth), Jilid II.

45 al-Imam Abi Daud Sulaiman al-Sijistani, Sunan Abi Daud, (Surabaya: Maktabah Dahlan, th), Jilid II, hlm. 255. 
al-Suyuthi, al-Imam Jalaluddin Abdirrahman bin Abibakar, al-Jami' al-Shaghir, Juz 1, (Surabaya: Dar al-Ihya al-Kutub al-Arabiyah, tth).

al-Syuwaisyi, Syaikh Muhammad Hafizh Ali, Tubfah al-'Urusy wa bi Hajah al-Nufus, Alih bahasa Abdul Rosyad Shiddiq, Kado Pernikahan, (Jakarta; Pustaka al-Kautsar, 2005).

Al-Turmudzi, Imam Abi Isa Muhammad bin Isa bin Tsaurah, Sunan Turmudzi. Jilid 2. (Surabaya: Maktabah Dahlan, tth).

Anshari MK, M., Hukum Perkawinan di Indonesia Masalah-masalah Krusial, (Yogyakarta: Pustaka Pelajar, 2010).

Anwar, Kasful, Nikah Sirri Melalui Wali Mubakkam di Kecamatan Tanjung Kabupaten Tabalong", Skripsi, (Amuntai: STAI Rakha, 2014).

Chairiaty, Ida, Implementasi Kebijakan Program Pelayanan Akta Kelabiran Gratis di Kota Banjarmasin (Studi Kasus Program Dispensasi Penerbitan Akta Kelabiran di Atas 1 (Satu) Tabun Tanpa Penetapan Pengadilan), Tesis, (Banjarmasin; Pascasarjana Univeritas Lambung Mangkurat, 2011).

Departemen Agama RI, Alquran dan Terjemahnya, (Jakarta: Proyek Pengadaan Kitab Suci Alquran, 1990/1991).

Departemen Agama, Pedoman Pembantu Pegawai Pencatat Nikah, (Jakarta: Badan Pembantu Kesejahteraan Masjid, 1991-1992).

Departemen Agama RI, Pedoman Pegawai Pencatat Nikah dan Pembantu Pegawai Pencatat Nikah, Jakarta: Proyek Peningkatan Sarana Keagamaan, 1996/1997).

Departemen P \& K RI, Kamus Besar Babasa Indonesia, (Jakarta: Balai Pustaka, 1990).

Ibnu Rusyd, Bidayatul Mujtabid, Jilid 3, (Jakarta: Pustaka Amani, 1995).

Ibnu Taimiyah, Hukum-Hukum Perkawinan, Alih bahasa Rusnan Yahya, (Jakarta: Pustaka al-Kautsar, 1997).

Majelis Ulama Indonesia, Himpunan Fatwa MUI, (Jakarta: Departemen Agama RI, 2003).

Muhammad Ismail al-Kahlani, Subul al-Salam, (Beirut: Dar al-Fikr, 1411 H).

Peraturan Daerah Nomor 12 Tahun 2009 tentang Retribusi Pelayanan di Bidang Kependudukan dan Pencatatan Sipil serta pelayanan lainnya.
Peraturan Presiden Nomor 25 Tahun 2008 tentang Persyaratan Tata Cara Pendaftaran Penduduk dan Pencatatan Sipil.

Rahman, Fatchur, Ilmu Waris, (Bandung: Alma'arif,, 1994).

Sabiq, al-Syaikh Sayyid, Fiqh al-Sunnah, Jilid II, (Beirut: Dar al-Fikr, 1403 H).

Sayyid Sabiq, Fiqh Sunnah, Jilid 6, (Bandung : Almaarif, 1987).

Shomad, Abd., Hukum Islam Penormaan Prinsip Syariah dalam Hukum Indonesia, (Jakarta: Prenada Media Group, 2010).

"Sumpah Suplitoir Machica Muchtar", Banjarmasin Post, 5 Maret 2013.

Syukur, Abdul Qadir, Wali Mubakkam dalam Pernikahan, Akibat Hukum dan Solusi, Tesis, (Banjarmasin: Pascasarjana IAIN Antasari, 2012).

Undang-Undang Nomor 1 Tabun 1974 Tentang Perkaninan, (Surabaya: Pustaka Tintamas, 1991).

Undang-Undang Nomor 23 Tabun 2002 tentang Perlindungan Anak..

Undang-Undang Nomor 23 Tabun 2006 tentang Administrasi Kependudukan.

Peraturan Daerab No. 11 Tabun 2008 tentang Penyelenggaraan Administrasi Kependudukan dan Pencatatan Sipil Kota Banjarmasin.

Zubaedah, Neng, Pencatatan Perkawinan \& Perkawinan Tidak Dicatat, (Jakarta: Sinar Grafika, 2010).

Zuhdi, Masyfuk, Masail Fiqhiyah, (Jakarta: Haji Masagung, 1996). 